\title{
米国ジョンスホプキンス大学医学部での研究生活
}

\section{山路ケーガン 加津代}

Department of Anesthesiology and Critical Care Medicine Johns Hopkins Medical Institutions

私は 2004 年 5 月より米国メリーランド州ボルティ モアのジョンスホプキンス大学医学部麻酔科にて肺 高血圧症，とくに肺血管系の血管障害，炎症に関す る研究を行っております。

私自身の日本での経歴は医学部出身の M.D. では なく, 生物化学系の学科を卒業後に鹿児島大学医学 部血管代謝病態解析学講座にて研究生として在籍 し, 論文博士号 (Ph.D.) を取得させていただいた後, 現在も所属する麻酔科, Professor Dr. Roger A. Johns 博士のグループヘポストドクトラルフェローとして 参加させていただきました，その経緯ですが, 当時, 私は血管内皮細胞と eNOS に関する研究をしていた ところ, Dr. Johns が肺高血圧症に関して，まさに同 じテーマの仕事をできるポスドクを Nature 誌で募 集しており，そこへ応募したことが契機となりまし た，CVをメールで送ったところ，数分以内に電話 インタビュー打診の返信が届き, 心臓が弾けてしま いそうに緊張した電話インタビュー(時差の関係で 早朝 5 時)を経て，また，たまたま参加予定であっ た米国血液学学会 $(\mathrm{ASH})$ に渡米するついでにインタ ビューに来て欲しい, というリクエストに応じて西 のサンディエゴから東のボルティモアを往復し， 1 日の間にラボメンバー全員と主要共同研究者の総勢 15 名と 30 分ずつの個人面接というハードスケ ジュールを敢行した結果, この職を得ることができ ました。私のボスは，英語が母国語でない人に対し ても容赦なく早口で話すタイプの人なので, 今で も，よくあの電話インタビューをこなせたなと思う ほどです。当時は日本人の海外への研究留学という と研究室のボス同士の話し合いで決まることが主流 だったように思われますので，私のようなケースは 珍しい方なのかもしれません。
私の所属するジョンスホプキンス大学は, アメリ カ政治の中心であるワシントン DC に近い都市, メ リーランド州ボルティモア市にあります。実業家 ジョンス・ホプキンス氏の遺産を基に 1876 年に世 界初の研究大学院大学として設立された私立大学で あり, 現在の職員数は約 3 万 4 千人で, メリーラン ド州の私立の施設としては最大規模とされていま す.また, The U.S. News \& World Reportによる“Best Colleges Rankings 2015” で米国内 10 位, とくに医学 研究においては Best Medical Schools, Research 2016 部門で, 1 位のハーバード大学, 2位のスタンフォー ド大学に続き, ジョンスホプキンス大学医学部は 3 位を獲得しています。ノーベル賞受賞者も多く(医 学・生理学賞では計 11 人), また付属の大学病院は 同じく The U.S. News \& World Report の病院部門で は過去に 22 年間連続 1 位を獲得しており, 最新の 2015-2016年版でも米国内 3 位を維持し, 医学研究, 臨床の両分野で高い評価を得ています。研究分野は 医学のみならず医学に関連した医療工学分野(Biomedical Engineering), 脳神経科学分野 (Neuroscience), 公衆衛生学分野 (School of Public Health)の研究も非 常に高い業績を挙げており, われわれ研究者にとっ ては学内での異分野間の共同研究 (multidisciplinary research)が実現可能であるという，この上ない魅力 があります。とくに近年は National Institute of Health (NIH: アメリカ国立衛生研究所) 由来の医学系のグ ラントは From Bench to Bedside を合言葉にした, 複 数の基礎研究と臨床系のラボからなるチームによる トランスレーショナルリサーチ, すなわち創薬や治 験に直結する成果主義のテーマへ大型資金が提供さ れる傾向が強まっています。

私自身は2004年より 2 年間のポスドクトレーニン 
グ後に Reseach Associateを経て 2012 年より Assistant Professor として約 11 年以上所属させていただ いていますが，その中でジョンスホプキンス大学医 学部の特徵として強く感じるところは, 医学教育, 研究, 医療の分野でリーダーシップの役割を果たし, また、リーダーとなる人々を育てるという使命感を 強く持っている点にあります。先ほど述べたような 幾つもの研究室が共同研究する形態の multidisciplinary research は，実はマネージメントが非常に難 しい研究体制であり，その研究全体をきちんと見渡 し，かつ研究の一体性を確保し，しかも権力を行使 できる立場に立つことのできるリーダーの存在なし には成功はありえない，と言っても過言ではないで しょう。その中でも私自身がとくに感じていること は, Principal Investigator(PI, 研究チームのリーダー) が医学・臨床系の出身 (M.D.) であるか，それとも基 礎系，バイオ系(Ph.D.)であるかによって研究体制や 教育体制がかなり異なる，ということであります。 基本的に基礎系の PI は研究，科学をロジックの積 み重ねにより完成させようとし，その部分について 突き詰めることが得意な人が多く，科学に対する完 成度を高めるためにはあらゆる論理的な批判を受け 入れることが可能である(あるいはむしろ批判をあ りがたく思う)一方, 臨床系の PI は, あくまでもヒ 卜を対象と前提の教育を受けてきているために, 科 学のロジックよりはチームの人々にいかに前向きな 姿勢で働いてもらうかというマネージメントの方を 重視する傾向があるように思います。

このように様々なバックグラウンドや異なる教育, トレーニングを受けてきた人々が一つのテーマに向 かって共同研究を行うことは容易ではなく, 結果と して研究が遅々として進まないという状況を私自身 も経験してきました。 とくに米国では日本とは異な り，様々な国，人種，文化の人々が寄り集まりチー ムを組んで一緒に仕事をしていかなければなりま せん，その試行錯誤の中で，日本人としてとても考 えさせられたことは，こちらの人々の思考の中ある いはプロジェクトを進めていく上で「ヒトの意見は 違っていて当然である」という前提がある，という ことでした。誰でも自分自身がそれぞれ論理的に考 え抜いた結果として「自分はこれが一番よい」と思う 自分の価值観がある訳ですが，日本の場合は大体に

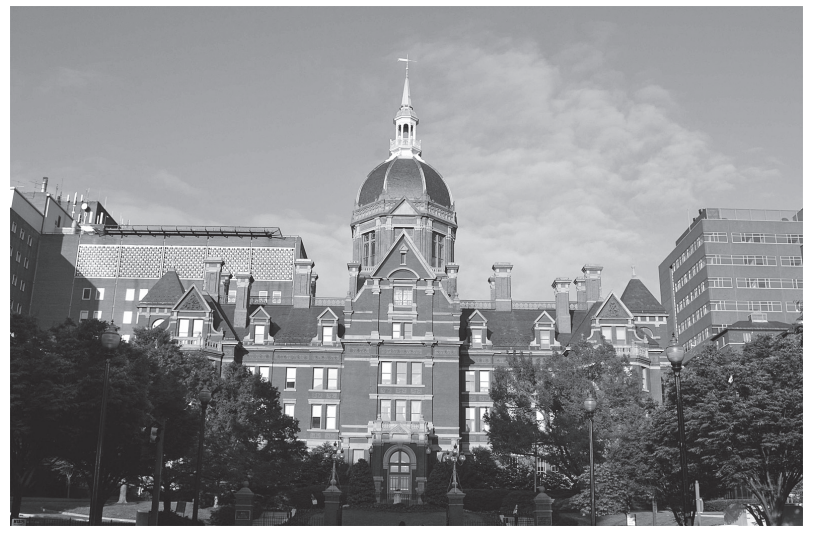

図 1 ジョンスホプキンス病院の正面玄関

おいて，その「価值観(意見)を一致させよう」という 方向へ努力を向ける傾向があるように思います。し かしこちらの場合は，全体の意見を一致させる方向 へ努力をするというよりは，「われわれの価值観・ 意見は異なって当然である。その相違を前提とした 上で，全体と個人にとって最善の利益を目指すには どうすればいいのか? 」という方向へ問題解決を求 める傾向があるように思います，英語で言うと「We agree to disagree」というところから問題提議が始ま り, 問題解決のための糸口が見えてくるように思い ます。ここで個々に必要とされる能力は「交渉能力 (Negotiation skill)」であり，とくにリーダーとなる 人材には, 科学的知識に留まらず, これらの問題解 決能力, 交渉能力, そしてそれを行使するためのコ ミュニケーション能力が強く求められるように思い ます。

そのような状況下, ジョンスホプキンス医学部は 医学研究，臨床そして教育の面でバランスのとれた リーダーを育成しようという試みを積極的に且つ組 織単位で体系化しています。例えば，若手の Assistant Professor (助教授) や Associate Professor(准教授) 向けには The Office of Faculty Development という組 織があり，上記に述べたようなリーダーシップやコ ミュニケーションスキルを向上させる講義に限らず, 研究者に必要な論文執筆術, 夕イムマネージメント, ネットワーキングの能力, また現在のランクから次 のランクへ昇進するために具体的にどのような対策 を取らなければならないか，などを体系的に学ぶ講 座を職員が任意で受けることができます。 


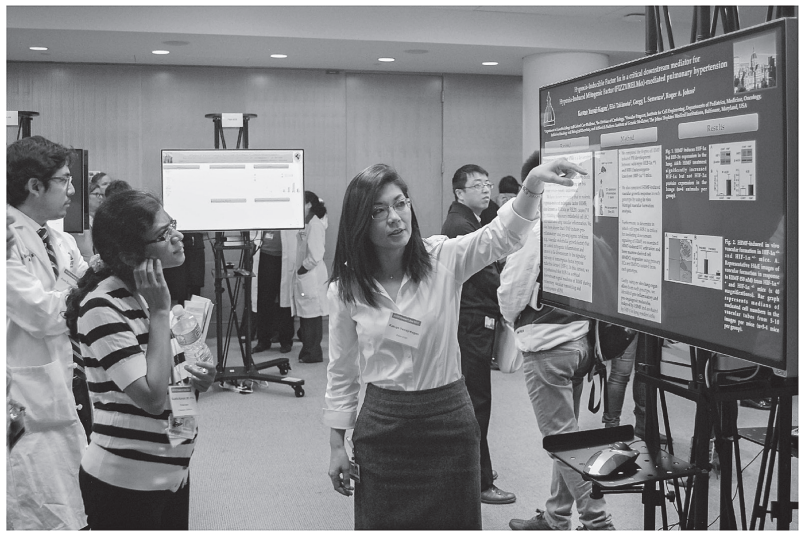

図 2 麻酔科内での研究発表会

麻酔科には心血管部門, 肺疾患部門, 神経学部門, 麻酔 学部門などがある。中央が筆者。

また最近日本では政府により，女性が社会生活に おいて男性と均等な機会を与えられるための女性活 躍推進法が制定され，その一環としてアカデミアで も女性研究者の雇用促進や機会均等が推進されてい るように思います。実はジョンスホプキンス大学医 学部はアメリカ国内でもかなり早い 1893 年に総合大 学としては初めて女子医学生を受け入れており, そ れ以来，女性の医師，研究者の育成には並々ならぬ 努力がなされています。 もちろん女性として「ガラス の天井」という言葉が存在し, それについてのディ スカッションはありましたが，私がポスドクを始め た 2004 年の当時から今までの間に, 自分自身が女 性であるために仕事の面で不利益や不公平な扱いを 受けたという経験，認識は全くなく，これは一重に 先輩の女性研究者の方々やそれをサポートしてくだ さったリーダーの方々の努力の上にある恩恵だと 思っております。また，学内にはべテランの女性教 授たちが率いる The Office of Women in Science and Medicine という組織が存在し，軽いランチを交えた 講義やネットワーキングのための夕食会などが定期 的に開催されます。特徴としては女性のみで運営さ れていることで, 若手の女性研究者がベテランの女 性教授陣にキャリアや，仕事と家庭の両立，女性で あるが故の職場での悩みなどを相談したり，経験談 を伺ったりすることができます。私自身も定期的に 参加させていただいていますが，やはり働く女性に とっては職場の身近なところに自分のロールモデル

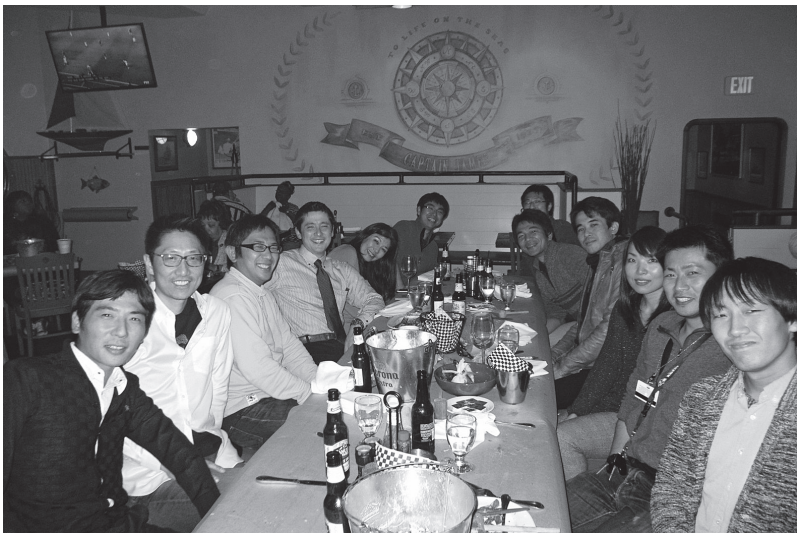

図 3 ジョンスホプキンス大学医学部循環器科・麻酔科の 日本人研究者による忘年会の様子

メンバーは呼吸器・救急, 循環器, 疫学などの研究に従事. ボルティモアは蟹で有名なので, 蟹専門のレストランにて.

になる方々が存在することが非常に大きな支えにな ります。とくに，現実にキャリアと家庭を両立され ているお手本を目の当たりにすることで「自分にもで きるかもしれない」という自信や「どうすれば希望が 実現するのか」ということを実際に相談し，アドバイ スを求めることも可能です。そのような環境がある かないかでは女性のキャリア促進には雲泥の差があ るように思います。また，女性に限らず，学内では 毎日のように非常にレベルの高い, 様々な研究分野 のセミナーや連続した講座が開かれており，学生や ポスドク, 職員, 客員研究員などが自由に参加でき るようになっています。

このように，われわれの大学の長所を述べてまい りましたが，もちろん撖しい面もあります。とくに, ジョンスホプキンス大学の職員, 研究員は, 周りの 公立大学などと比べると, 要求される外部研究費獲 得のハードルが非常に高く, 日々, 切硡环磨し常に 結果 (この場合, 研究費獲得数, 出版した論文の質 と数, 研究分野への貢献, また受賞歴など)を出さ なければ生き残ることができないというストレスの 高い現実があります。しかしながら，この厳しい競 争システムこそがわれわれの大学のレベルを高く保 つことを可能にしている面もあり，一概に否定する 訳にはいかないという面もあるように思います。

またジョンスホプキンス大学医学部には常時約 100 人前後の日本人研究者が施設内で研究に従事し ています。医学部キャンパス内にはJapanese Sci- 
ence Seminar in Baltimore(JSSB) という日本人のネッ トワークもあり, 月に一度の研究発表会が開催され ています。

近年は日本の科学技術力や教育レベルも非常に高 いために，若い研究者がなかなか海外留学をしよう としない，という意見を伺います。確かに一定の分 野では日本国内の研究レベルが世界を率いていると いうこともあると思いますし，その面では質の高い 論文をわざわざ海外に出なくても出せる，というこ ともあるかもしれません，しかしながら私個人とし ては，日本の医学研究を担っていく方々，また将来 リーダーとして活躍される方々におかれましては, ぜひ研究をして論文を出す，ということに限らず， ぜひ一度，日本という環境から一歩外に出て，日本 の常識が通用しない世界の中で人々がどのような形 で交流し，仕事をし，チームやネットワークを形成 し，意見を交わし，物事を決定し，組織を運営して いくのか, という過程をぜひご自身の目で見て経験
をしていただきたいと思っています。もちろん，ア メリカにも問題点はありますし，アメリカのやり方 をそのまま日本へ持ち込んでも，それが上手くいく とは限らないでしょう。それでも，日本という枠か ら一旦出て, 全く異なる価值観を知ることだけでも, その後の人生を大きく左右するような経験になると 断言できます。私自身はアメリカの地で残りの研究 生活を遂げることになると思いますが，一人でも多 くの日本人研究者の方々に海外での研究生活を経験 していただき, 日本の医学研究の発展に繋がってい ただけること，また何よりも研究者の方々自身が幸 福を感じることのできる研究生活のあり方を発見し ていただければ幸いです。

最後になりましたが，このような貴重な執筆の機 会を与えていただきました鹿児島大学大学院医歯学 総合研究科の橋口照人教授に心より感謝申し上げま す. 